\title{
Rethinking Digital Media and Political Change
}

\section{Introduction}

This paper proposes a new theoretical perspective on how the internet has changed politics. It adopts a comparative-historical perspective and focuses on changes in how elites communicate with the public about politics. It compares two countries, Sweden and the United States, and examines the political uses of digital media, including Facebook, Twitter, blogs, and use of the Web for accessing information online. The paper asks: what effects do digital media, compared with traditional media, have on the interaction between political and media elites on the one hand and the audiences or publics of these media on the other?

We shall see that the main differences between the media systems of the two countries persist Sweden's public service media as against America's predominantly commercial media - even as political communication has shifted online in both countries. Yet what we also see is a convergence between the two countries with digital media - insofar as political and media elites increasingly monitor publics and insofar as publics increasingly diversify their intake of political information. While these two shifts lead to greater responsiveness of the political system to the public, they also provide scope for a more managed and targeted uses of communication by elites. On the part of the public, on the other hand, digital media diversify the sources of political information and reshape the practices of becoming engaged with politics. Nevertheless, this input into politics has limits which are ultimately given by the extent to which the public foments political change via media. This double-edged nature of new technologies in promoting political change can be seen as part of a longer-term trajectory of the increasing mediation of politics. The shift online therefore also requires rethinking the role of media: away from mass and interpersonal models, and towards a theory 
whereby a greater differentiation within media systems is at the same time subject to the limits of attention and the limits of more diffuse political engagement.

The main contribution of the paper is to synthesize what is known to date about digital media in Sweden and the United States within a new theoretical framework. This contribution is worth highlighting to pre-empt the potential criticism that this paper contributes no new empirical material: true, but the current gap is not as much in data or in empirical research about traditional and new media in political communication - as it is in making sense of these materials within a framework that can pinpoint the changes that have taken place by means of historical and comparative analysis of media systems as wholes. The contribution here is to put these changes into a broader perspective, which is so far lacking for digital media. Previous efforts focus on single countries or on single media or on individual political campaigns and the like. This paper begins by noting the shortcomings of existing analyses of political communication and the lack of a model of how digital media work in a way that is different from traditional or mass media. Next, the paper gives an account of political communication in Sweden and the United States, comparing traditional and new digital media. The final part of the paper develops a framework for understanding digital media which highlights how they extend and diversify the public sphere, even as this sphere is limited in terms of the visibility of political issues.

\section{Overcoming the Shortcomings of Existing Theories of Digital Media and Politics}

If we want to understand how digital media affect political change, one point of departure is how the public - or 'the people' or citizens - use information and communication technologies (ICTs) to become informed and participating citizens. This is one side. The other side of the equation are political institutions (the political apparatus of the state and those who govern) and media institutions (news producers and journalism and media professionals) - the elites which receive 
inputs from citizens as well as providing them with information. The measure of political change should be the responsiveness of the political apparatus to citizens, and how this responsiveness is mediated. In this respect the media are a transmission belt, albeit one where media are limited to include only politically relevant communication and information that provides a representative and plural set of inputs into the political apparatus. In a democratic society these inputs should, as much as possible, not be skewed towards powerful elites or towards particularly powerful groups (Dahl 1998).

In discussing political communication, the term 'citizens' can be used to describe the aggregate inputs into the political process. It would be equally appropriate to use 'the people' or 'civil society' or 'the public' (indeed, 'public' will be used interchangeably with 'citizens') to refer to the interests that are expressed in society, which excludes market interests (the economy) except insofar as they constitute politically-relevant interests. It is also useful to counterpose citizens to elites - political and media professionals (and economic elites insofar as they are politically relevant actors): elites set the media agenda, but they must also be responsive to the mediated agendas of citizens or of the public. Political communication and information is concentrated among elites who dominate the agenda of traditional and digital media; indeed, as Schudson (2011) has pointed out, the vast bulk of sources for news are political officials. Finally, 'communication' involves two-way messages or oneto-many messages, whereas 'information' means obtaining knowledge or data that makes a difference - in this case to politics. 'Media' encompasses both.

Having clarified how several concepts are used here, an important theoretical premise deserves highlighting: in focusing on how media constitute the transmission belt of political responsiveness and politically relevant input, an implicit premise is that the political system can be separated from the economic and cultural systems (or political power separated from economic and cultural power). This separation is not controversial in mainstream political and social theory (Schroeder 2013; or for 
example Mann 2013: 154-166). A consequence, however, is that even though media systems have, as Hallin and Mancini (2004) argue, become autonomous, they are a 'subsystem', the transmission belt within the political system (even if media subsystems also, of course, separately serve the cultural system or cultural power, as with entertainment, or the economic system, as with marketing and advertising for example). This is why, although Williams and Delli Carpini (2011), among others, have pointed out that what is 'political' has widened beyond traditional media with digital media, they also say that it is nevertheless still important to delimit what falls within politically relevant media and responsiveness and input - and I will follow them in this respect. As we shall see, this has implications for being able to delimit the aggregate mediated responsiveness and input across all media, traditional and new or digital, in terms of the overall limits of visibility or attention and agenda-setting. This is a point to which we will return in the conclusion.

It is not necessary to go into detail about the shortcomings of current theories of media and politics since a number scholars (for example, Bennett and lyengar 2008) have pointed out that digital media do not fit into the mass media (or broadcast) models that still dominate. Many studies have analysed individual digital media or examined single countries, but no studies to date have attempted to contrast traditional and digital media in a holistic way, as this paper aims to do. A possible exception is Castells (2009), who argues that networks have become pervasive, with the central conflict between globally dominant media corporations ranged against often transnational social movements. This theory crucially leaves out the nation-state within which politics is primarily bounded, as are the media systems (Hallin and Mancini 2004) that operate within them, and thus media systems (pace Castells) shape and take on different nationally bounded forms among the varieties of capitalism. Further, Castells hypostatizes a 'network society', which again does not distinguish between different media systems and also subsumes the difference that new technologies make under various types of networks. 
However, even if much of political communication and information is moving online, it is worth bearing in mind that the vast bulk of political responsiveness and inputs still take place via traditional media (and so not via digital or electronic networks). Nevertheless, an assumption will be made here (akin to Castells' idea of a network society) that the most advanced digital media practices described below will become commonplace in the future: in other words, that even though the changes made by digital media are still straws in the wind, they are bound to intensify (the conclusion will come back to this point). Hence this paper will also take issue with another theoretical perspective that has been put forward, by Chadwick, that politics and the media (in the United States and the United Kingdom) are currently in a 'hybrid' transition from old to new: he argues that 'the Hybrid media system exhibits a balance between the older logics of transmission and reception and the newer logics of circulation, recirculation, and negotiation'(2013: 208) with the balance still skewed toward the older logics (2013: 209). Where the argument will depart from this view is that even for the newer logics, it must pinpointed exactly how these depart from the older logics in terms of their effects and workings. Second, Chadwick concludes (for the United States) that 'political communication...is more polycentric than during the period of mass communication that dominated the twentieth century ... the opportunities for ordinary citizens ... are on balance greater than they were ... [though it] is primarily political activists and the politically interested who are able to make a difference with newer media'(2013: 210). This overlooks, first, the way that political and media elites (not just 'ordinary citizens') are also able to make more powerful uses of new media to monitor and respond to the public and second, that new media change not just those who are active and interested in politics, but also diversify the agenda and visibility somewhat for wider groups, including political 'outsiders', in terms of the means provided by new media for political input and access to political information.

Another theory that potentially overcomes the focus on individual media is agenda-setting theory (McCombs 2014) where, as we shall see, some studies have begun to examine how the agenda 
changes with the shift from old to new media (for example, Neuman, Guggenheim, Mo Jang and Bae 2014). Agenda-setting provides a means of understanding the topics that are foregrounded by the media; not what media make people think, but what it makes them think about. However, while this theory is able to gauge agenda-setting across media, it leaves open the question of how the aggregate political agenda is translated as between elites and citizens; in other words, it is a theory of media rather than of the media in society (as here). Further, this theory leaves out that there is a limited attention space across all media such that only certain topics become so prominent as to translate into political change. Bimber says that 'competition for political attention [is] growing more aggressive, against a background of largely unchanged habits of political knowledge and learning' (2003: 230), which leaves unanswered what the effect of this greater competition might be.

Thompson (1995) similarly speaks of a 'struggle for visibility', but again, he leaves open whether new media create more space in this struggle. There is no theory which recognizes that, as I will argue below, even if new media expand the diversity and volume of politically-relevant information, there is only a limited window across all media for fostering political change: on a rolling basis, this is a zero-sum window, unless new social forces enter politics, or if new technologies generally broaden the input of citizens. As we shall see, they do so importantly but marginally. In any event, even if some agendas cut across media systems, the main unit for analysing political communication which allows us to gauge this limited attention space are countries with different media systems, and we can now turn to two of these.

\section{Comparing the Swedish and American Media Systems}

The media systems of the United States and Sweden make for a useful comparison since the two countries have similar levels of technology adoption but they are pure types at the extremes of the continuum among advanced societies in terms of their politics and economies (Schroeder 2007; 2013) for the rationale of using these two cases). They also exemplify two quite different media 
systems in Hallin and Mancini's (2004) schema, which contrasts democratic corporatist countries (such as the Scandinavian countries and Germany) with liberal countries (foremost the United States, but Canada and the UK - partly - also fall into this category) (A third category, polarized pluralist, with countries such as Italy and Spain, falls outside the scope of this paper). The details of this schema are only needed here inasmuch as they shed light on how digital media depart from traditional ones, and the key difference is between a market-dominated system in the US and strong state intervention and a tradition of public service media in Sweden.

We can turn first to the United States. The impact of the media on politics has been studied in more detail for the American case than anywhere else. What gets lost in research on recent changes is that apart from a more market-oriented media system, American media are shaped by the political gridlock of a two party system (Hallin and Mancini also discuss the differences between political systems, but focus on government rather than institutions). The implication is that political news concentrates on the horse race between two antagonistic political ideologies on the one hand and on the antagonism between the President and Congress on the other. Recently, there has been a discussion whether the media have contributed to the polarization of ideologies and its adherents within this two party system (Baum and Groeling 2008). Yet this polarization has to be put in the larger comparative context whereby the two parties will continue to dominate, and they must therefore also continue to appeal to the middle ground in order to win elections, howsoever polarized the media and ideology have become.

One analysis related to polarization and the American media system nevertheless deserves detailed discussion: Prior (2007) has made the case, which seems paradoxical at first, that increased media choice results in less political knowledge - at least among a portion of the population. This argument rests on a long-term perspective on American media. As Prior points out, television (TV) news made political information more accessible to a broader American population in the 1960s and 1970s since 
it no longer required the literacy skills of newspapers on the one hand and because the news on the three dominant TV channels was the only content that was available in certain time slots during 'prime time'. In this way broadcast TV levelled the playing field.

This levelling ceased to be the case from the late 1970s onwards, when cable TV - and more recently the Internet - increased viewer choice, which meant that some viewers turned away from news and to entertainment: 'Summing across all media, the total amount of news and political information that Americans read, watch, and hear has, if anything, increased recently (even on a per capita basis). With regard to all elements of political involvement ... - news consumption, political knowledge, and turnout - the mean has been remarkably stable, while inequality has increased. The latter is the crucial effect of greater media choice' (2007: 265). By 'inequality', Prior means that some watch more news while others prefer non-news content. Put differently, the result of choice is that some watch as much if not more news, but others prefer entertainment and watch less news, becoming less interested in - and less knowledgeable about - politics in the process.

For Prior this is important because those who prefer entertainment are also less partisan about their politics, which in America means, in view of their lesser likelihood to vote, that they are also less likely to curb those who prefer more news and who are more partisan, thus contributing to polarization in elections. Irrespective of this polarizing effect, we can focus here on several aspects of the argument that greater choice leads to parts of the population becoming less politically interested: First, Prior says that this does not entail a technological determinist argument, but he contradicts himself on this point. He says that technology is not the only factor because it also matters how technology is regulated, how it is shaped by the economy, and its uses (2007: 24), but he also says that 'rising inequality in political involvement' is 'a result of voluntary consumption decisions...technological progress is the ultimate cause of this rise'(2007: 281). But consumption decisions depend on the choices that technology makes available in the first place, and in this case 
clearly it was the advent of cable TV and the Internet that enabled these choices (and Prior admits as much when he talks about the 'ultimate cause').

The increased choice environment is, of course, not limited to the United States. But its implications might be different in media systems that also have public broadcasting, and Sweden has had a public broadcast system and the state has also subsidized newspapers, policies that are aimed at enhancing diversity and promoting the public interest. An important change nevertheless took place in this media system with the introduction of competition by commercial TV in Sweden since the 1980s. Thus we can ask whether similar changes have taken place in Sweden to those identified for America by Prior? To be sure, growing competition among commercial media in Sweden, as in the US, has meant that marketization increasingly overrides the differences between the two types of (Hallin and Mancini) media systems. And Westlund and Weibull (2013) also document similar changes to a more market-led choice environments (as did Prior). Using surveys that capture several generations (those growing up before World War 2, the post-war baby boomers, 'Generation X', and the recent generation growing up with digital technologies) as well as changes in media use over the life course of individuals, they document and analyse changes in news consumption between 1986 and 2011 across all media.

What Westlund and Weibull show is that although the earlier generations stick to public service media, there is a shift away from public service to commercial TV and radio among the younger generations. The same applies to print newspapers, where the younger generations have shifted to digital versions. Recently there has also been a shift away from paid-for quality newspapers to free ones (Metro) and to mobile news consumption. And a more recent analysis shows that among 16-29 year olds, a higher percentage reads newspapers on mobile devices than in any other format, digital or print (Weibull and Wadbring 2014: 327). So while newspapers and public service media still dominate among the population as a whole, this is not the case among the younger generation and 
those at an earlier stage in the life course. Westlund and Weibull point out that this is not a question of complete displacement: the earlier generations add to their repertoire of news consumption with commercial broadcasters and online versions. Nevertheless, there is an unmistakeable shift away from print newspapers and public service news to more diversified sources of news and online news among the younger generations and for those at an earlier stage in life.

Despite similar shifts towards more market competition and more diversity, the two media systems remain distinct: Sweden is a more newspaper-centric society, the United States a more televisioncentric one (Norris 2000: 85; Norris and Inglehart 2009: 58-9, Aalberg and Curran 2012). In Sweden, public service remains dominant and in the United States, the three networks still have a large audience share even if people spread their viewing hours rather evenly, including those who watch Fox News for example, across many channels in an environment of several broadcast and many cable channels (Webster 2005: 378). However, the two systems have also converged: there is increasing the competition for audiences, not just in Sweden but also in America with increasing deregulation. This market-orientation has attenuated the differences in Hallin and Mancini's typology, but so has the proliferation of technologies - not just satellite and cable - but also online news consumption.

Overall then, in both countries, there is a continuing diversification: in America, away from the three main broadcast news channels and away from local and print newspapers; in Sweden, away from public television and away from local and print newspapers. These changes are taking place slowly, but even if the shift towards digital visual and textual news consumption is furthest along among younger people, it is a shift that will intensify over time. Mass media, print and broadcast, will fade. The implication is that audiences select their news and political information more. However, as argued above (and will be spelled out in more detail below), there is a limited attention space for mediated politics, so that this diversity pertains primarily to how material is accessed rather than 
what content is accessed. Increased selection could lead to an intensification of the 'Prior' effect, but it also means (as we shall see) that elites must cater more to the diversified needs of citizens on the one hand, and citizens must take a more active part in managing their needs for political information on the other.

\section{Digital Media in Sweden and the United States}

With digital media, there is an increase in the mediation of politics: there are more formats, such as disseminating news events via Twitter, or sharing content on Facebook, or commenting on politics in blogs, or accessing online-only news websites. There is also far more content available. But while the addition of digital to traditional media is not zero sum in terms of media consumption, there are limits to the effects of digital media on politics: more diverse inputs from society must become part of an overall input into the political apparatus, and this overall input must be managed more in sense of 'governing with the news' (Cook 2005). Put differently, these inputs must compete in the 'marketplace of ideas' (Asard and Bennett 1997), and they are increasingly actively managed by political and media elites to do so.

We can begin with digital media in politics with Sweden. Here public service TV continues to have a have a large (36\% in 2007) audience share (Aalberg, Strabac, Brekken 2012: 18). But Swedish public media are also going online (as are American public media, the Public Broadcasting Service and National Public Radio, with much smaller audience shares). There are a number of studies that have examined digital media uses among Swedish politicians and journalists. Larsson and Kalsnes (2014) analysed the use of Twitter and Facebook by politicians and found that Twitter is more popular than Facebook, which they see as a mismatch because Twitter is mainly used by media-savvy urban elites whereas Facebook enjoys a wider popularity. They also found that both social media are used more by politicians who are 'underdogs' and 'tend to be younger, non-incumbents' and outsiders rather 
than prominent insiders (2014: 12). Larsson and Moe (2012) gauged Twitter uses during the 2010 elections, when there was a concentration among journalists, politicians and political bloggers, with few conversations involving the public and few replies to tweets. This is similar to the finding by Hedman and Djerf-Pierre (2010) that journalists mainly use Twitter for self-branding rather than engaging in conversations with their readers or viewers. The same applies to tweeting in relation to talk shows which feature politicians and current affairs guests: Larsson (2013) examined a whole season of a popular talk show and notes that the top tweeters were all journalists whereas a broader public did not become involved in the programme.

Gustafsson's (2012) highlighted what is acceptable in mainstream political discourse with his examination of Facebook use in Sweden which used qualitative methods to study party and political interest group members (and non-members). He found that Facebook was seen as a useful tool for political engagement in terms of coordinating action, recruiting new members, and communication among members. At the same time, he also noticed a reluctance to engage in politics on Facebook because of worries about revealing political preferences to potential employers or to friends. As for Facebook uses by Swedish political parties, Larsson (2014) measured this in 2013, counting numbers of posts and shares and likes as indicators of levels of use. He found that although Facebook use was limited, it nevertheless favoured the smaller parties that might otherwise not receive as much media attention as the major parties.

Here we can note that these smaller parties include 'outsiders' such as the Sweden Democrats, the populist anti-immigration right-wing party which has in recent years been in the ascendant: social media may be a more useful channel for communicating to wider audiences for the Sweden Democrats since this political position is unacceptable in mainstream public discourse. Larsson, for example, found a 'tendency for ideologically marginalized parties to gain more traction in novel media spheres than in the coverage by curated by established media actors' (2015: 12) during the 
2014 Swedish election, which also benefitted other smaller parties such as the Feminist Initiative and the Pirate Party. However, unlike these two parties, the Sweden Democrats were no longer marginal by 2014 , gaining the third largest share of votes (they had already passed the $5 \%$ threshold of votes to gain seats in Parliament in 2010, unlike the other two). Some polls have subsequently, in the wake of the migrant crisis, put them ahead of all other parties (https://yougov.se/news/2015/08/20/sd-ar-sveriges-storsta-parti/), even though they have been blocked by an alliance of the conservatives (Moderaterna) and Social Democrats from having much influence in government. At the same time, the Sweden Democrats, whose popularity predates the migrant crisis (the party was founded in 1988) have a history of being ignored by other parties and in the mainstream media (Hellstroem, Nilsson and Stoltz 2012). But since they claim that mainstream media ignore them, apart from using social media, they have also kept up a lively online presence via a number of online only newspapers that are connected to or sympathetic to the party.

To these accounts of the uses of new digital media by media and political elites, we can add that more than half of all Swedes aged 26-55 use the internet for news on a daily basis, all ages do so occasionally, and those under 46 regard the internet as the most important source of news - with TV far behind (Findahl 2014: 65, 66; Findahl and Davidsson 2015: 82). Yet the total amount of time devoted to reading news, both on paper and online, has remained rather constant since the 1980s (Findahl 2014: 66). There are no figures for overall news and political media use, but we can see (from the Westlund and Weibull paper discussed earlier) that there is some displacement and some complementing of traditional media. We have also seen that there is some circumvention of gatekeepers (with less acceptable content). But apart from this, there is no large entry of new political groups as a result of digital technologies, nor a large broadening of the agenda.

For the United States, as mentioned earlier, one of the major debates in relation to digital media has been whether they contribute to political polarization. Analysing Twitter during the 2012 American 
presidential election campaign, Barbera and Rivero found that 'political discussion in Twitter is mainly driven by citizens with extreme values in the ideological scale, a situation that certainly favors the level of political polarization of the political discussion on Twitter' (2014: 11). Along similar lines, Baum and Groeling (2008) found that political blog websites (Daily Kos on the Left and Free Republic on the Right) featured far more partisan news stories than the news stories that were top-ranked on the news wires (Associated Press and Reuters, which could be regarded as presenting a balanced set of stories). The polarization thesis remains contentious, however: Messing and Westwood (2014) showed that endorsements of news items via social network sites (such as Facebook likes) could prompt more people to read these items. Hence - since peoples' social networks are likely to be diverse and their recommendations for news items cut across partisan political lines - these endorsements could help to overcome rather than to increase political polarization.

As in Sweden, the use of Twitter in politics is mostly confined to elites and does not generally lead to more involvement or conversations with a broader public. Golbeck, Grimes and Rogers (2010) found that members of Congress used Twitter mainly for self-promotion rather than for engaging with the public. Similarly, having a Facebook site, which has become the norm among candidates for the national election in America in 2012, mainly means that they push information about their activities to their publics (Gulati and Williams 2013). In any event, the most widely discussed use of digital media in politics has been in relation to presidential election campaigns. Bimber (2014) argues that the Obama campaigns of 2008 and 2012 were the most advanced to date in using digital tools, including using data analytics or big data to target particularly critical voters (see also Chadwick 2013: 137-58). Obama's campaign team also analysed, among other things, people's social networks, including on Facebook and Twitter. Bimber says that this strategy took personalized political communication to a new level, and that it has been copied by Republicans and will be taken even further in future election campaigns in America and elsewhere. 
One outstanding example, similar to the Sweden Democrats, can be found for the circumvention of traditional news gatekeepers in recent American politics: during the 2016 presidential primaries, Donald Trump dominated the news headlines on the side of the Republican race to become the nominee, even though he was a party outsider and the party favoured other insider candidates. His dominance appears to have been achieved largely because of social media, and mainly Twitter (though some YouTube advertisements also contributed), where he tweeted controversial positions on a range of issues. These positions then featured prominently in television newscasts and newspaper headlines. Many of these headlines were critical of Trump's positions, which were far from the political mainstream and promoted a populist right-wing agenda, including most controversially an anti-immigrant stance. Yet the headlines ensured that his views received a disproportionate amount of attention (the relation between number of tweets and coverage in mainstream for all the primary candidates over the course of the campaign can be tracked at http://viz2016.com/, and for the corresponding polling data on the Republican side, http://www.realclearpolitics.com/epolls/2016/president/us/2016 republican presidential nominati on-3823.html). Traditional news media were forced to give a lot of time to Trump's views since the American system is characterized by horserace politics and market competition for audience share, and Trump's views were good for media ratings, as media executives recognized, added to which 'free' extensive media coverage meant that Trump had to spend far less on political advertising than his rivals (Tomasky 2016).

There is a strong parallel with Sweden: Trump's position would not have achieved prominence had it not been supported by a substantial proportion of the electorate. The base of support in both cases consists of a part of the population that considers itself left out by the countries' media elites and its established party elites. And while there is an economic aspect to its support, this base of support is less educated, more male, more white or native born, and more against established state elites: its anti-(im)migrant, anti-refugee and anti-Muslim stances are more to do with citizenship rights and 
economic nationalism than with a purely economic rationale. However, there is also a major difference between the two countries: in the US, the focus is on the horserace between candidates who rely on personal media attention (as opposed to attention to parties and policies), within a media system where news is driven more strongly (and exclusively, unlike Swedish public media) by market competition for audiences. Thus in Sweden, the Sweden Democrats can be kept out of traditional media but still maintain online visibility and receive attention in traditional media, while in the US the right wing populism which originated in the online realm (Twitter) acts as a transmission belt to visibility in traditional media. In the US, such visibility is essential for a viable campaign for national leadership, unlike in Sweden, where the Sweden Democrats as a party have been vying for a share of power in a multi-party system.

Again, these findings need to be put in the contexts of Americans' use of the internet for politics. Social network sites are becoming increasingly widespread among all generations in the US (Duggan et al. 2015), and according to Pew (2015), 61\% of Millenials, for example, received their news from Facebook. Ideally, as argued earlier, the input from society into the political apparatus should reflect society in an increasingly democratic way, representing its interests more inclusively or accurately. Yet Schlozman, Verba and Brady (2010: 501) found that higher socio-economic status groups are more likely to use the internet for various kinds of political participation than lower ones. This finding for the US can also be put into a broader and comparative perspective: the divide between higher and lower socio-economic groups applies to news media generally, but it is more acute in the US than in Sweden. At the end of a study which systematically compares news and political knowledge in the US with Northern Europe, Aalberg and Curran say that 'the American system, ultimately geared to optimizing high earnings expectations, makes little attempt to shrink the knowledge gap between the privileged and the underprivileged' (2012: 199). In other words, the media system, and in particular its public service component, makes a difference to how welleducated citizens are in public affairs. 
In terms of the internet, there may also be an age divide: young people use the internet more for political participation than older ones, but it is unclear whether this is a generational effect or a lifecycle one (with the implication that it will fade over time). It is true, as Nielsen and Schrøder (2014) document, that Americans and Danes (who, in terms of the nature of the media system, are similar to Swedes) have not shifted wholesale to using social media as a vehicle for news. However, the proportion who share a news story or who comment on a news story in an average week via social networking sites is more than $20 \%$ in the United States and more than $10 \%$ in Denmark (though in the 15-35 age bracket, social media have 'surged' as a source of news, to over half; Schrøder 2015: 66).

There have also been a number of studies which compare the content of the two media systems. Some of these confirm that the difference between the two types of media systems have persisted into the era of digital media. So, for example, Dimitrova and Stroembaeck (2011) compared election news in America and Sweden, and found that Swedish public television is more issue-focused while American television (and Swedish commercial television news) frame elections more as a horse race. They also found that election news content is governed more by a media logic in the United States, which foregrounds the role of journalists, whereas in Sweden the political logic is more pronounced and thus more prominence is given to politicians. In both systems, however, both public and commercial news used an 'interpretive' and a 'descriptive' journalistic style equally (though it should be noted that the analysis included only 'functionally equivalent' major news programmes - ABC, CBS and NBC - and excluded around the clock news such as CNN and Fox News). In sum, the Swedish and American systems continue to be different, but in both systems, commercial media overlap more. 
A different way to compare the two systems is from the side of what audiences take away from the media - rather than what is provided. In this vein, Curran, Iyengar, Brink Lund and Salovaara-Moring (2009) compared the American market-driven media system with the Scandinavian public service model. They measured the kinds of TV and print news produced by these systems for a certain period and then gauged public knowledge at the end of this period. They found, among other things, that 'the public service of broadcasting gives greater attention to public affairs and international news, and thereby fosters greater knowledge in these areas, than the market model' (2009: 22). Furthermore, as we have seen, there is less of a gap in knowledge between different socio-economic groups in Scandinavia compared to the United States.

Finally, we can turn to the use of digital media for political activism. Here it can be expected that these are similar across both media systems (and beyond) since this depends mainly on the extent of ICT adoption. There is agreement among scholars that the internet has changed digital activism somewhat. Earl and Kimport (2011: 10) argue that the main advantages of political online activism are reduced costs and also the aggregation of actions without physical co-presence. Bennett and Segerberg add that online activism need not be about organized mobilization; digital media also provide 'personal action frames' (2013: 36-40) whereby people can participate in activism on their own terms, sharing issues with distant others beyond boundaries of groups or ideologies that may be required in offline activism. These changes in political activism are similar to the broader changes that have been discussed so far: political communication becomes more personalized in a media environment that is more diversified. In addition, there are enhanced possibilities for coordinating activism. But this enhancement is a marginal addition because the media environment is already saturated; activist inputs only add to an already crowded set of media inputs, and within the overall aggregated inputs, there is a limited attention space and competition for visibility. Even so, gatekeeping can be expanded somewhat when new media can circumvent or provide new inputs into traditional ones, as we have seen with other marginalized actors. 


\section{Conclusion}

The differences between media systems persist, but apart from marketization, there are also convergences with new media just as there were with traditional media. Overall, new media have made for an incremental extension of political communication - more mediation - which adds to, displaces, and complements traditional media. Hence there is a gradual increase in the density of political communication between political and media elites and citizens in both countries. But this leads to social change only inasmuch as forces on both sides take advantage of the openings that new technologies provide, which have so far mainly consisted of using media more and targeting them better by elites on one side - and more diversified access and lower costs of engagement on the side of citizens or civil society plus added inputs from marginalized or 'outsiders'. The difference this makes to the political system is a greater responsiveness to the expanded aggregate inputs from the media system and from citizens by managing them more - where managing means responding to how the agenda is shaped by the public, mostly via media. The change is incremental - adding to and complementing traditional media rather than constituting a break with them - because for a radical break, two conditions would have to apply: one is that new media expand and diversify political engagement from either or both sides. As we have seen, this is indeed the case. The second condition however is that there would need to be social forces that make use of new media to drive this engagement, and such forces are hard to detect at present, except for examples like the populists who are less visible in traditional media. These points can now be elaborated in more detail.

One way to highlight that the change is only incremental in media-saturated societies (or where there is a limited attention space) is by contrasting this with this with the situation in societies which are not media-saturated. In societies where media adoption is still limited or constrained by an 
authoritarian political system, new digital media can reshape the flow between publics and the political system (Howard 2010). New media are used in China, for example, in the place of official media, and there has been a rapid increase in the competition among commercial media, including new ones, even though both are subject to the strictures of state control (Stockmann 2013). Put differently, new media in this case play more than an incremental role (at least potentially, insofar as they are not curbed) because they add to the inputs to the media subsystem which is otherwise constrained for traditional media. Hence too the authorities need to try to control these new media much more than traditional ones. This is unlike Sweden and the United States, where there is limited scope for new digital media to make a difference - given that an increased flow would need significantly to enhance political informedness or engagement or the responsiveness of the political system to citizens. But this enhancement is limited, since macro-sociology tells us that overall, political change from below has been constrained in advanced democracies in recent decades (Mann 2014; Schroeder 2013), and in some respects, as we have seen, new digital media diminish news consumption and political knowledge. Digital media allow some degree of circumvention of gatekeeping institutions everywhere, but in a political communication environment with many channels and formats, and where the balance of media power between political elites and people is relatively stable, large-scale changes cannot be expected, even with greater density of mediated politics.

Further, even if responsiveness is changing incrementally, the result is also that this responsiveness can be used by political elites to enhance their legitimacy, unless citizens can express their political demands more forcefully. It can be highlighted why this limitation is important: politics plays the central direction-giving role in society, and citizen inputs into this process take place mainly via media. As Luhmann put it, in a claim that is only slightly exaggerated, 'what we know about our society, or indeed about the world in which we live, we know through the mass media (2000: 1). If this seems a trivial point, it can be noted again that in countries such as China, where digital media 
have rapidly become a more powerful vehicle than traditional media for expressing forceful demands, the implications are different: in these countries, unlike in developed democracies, the political system has to be much more active in managing these demands in order to contain them. In other words, in these countries, the role of digital media is more important both on the side of more forceful inputs or demands and the need to contain them, unlike in developed democracies.

This point can be put differently: as mentioned at the outset, the idea of a limited attention space, or competition for visibility (Thompson 1995), provides the constraint for how politics is communicated. More diverse sources of political information and engagement do not necessarily make a difference unless they expand the scope and forcefulness of inputs vis-à-vis the regime. But if we think about where we can find this expansion, then it is where digital media have rapidly become more important than traditional media and where, at the same time, politics has become unsettled. In Sweden and in America, as we have seen, this expansion has been incremental but significant. Where new actors such as populist right wing forces come onto the scene in a way that affects politics in a major way, they can take advantage of new digital media to circumvent traditional ones, though again, this effect is shaped by the respective media systems (public media in Sweden, audience competition in the US). Communicative responsiveness has become somewhat denser, but it is still subject to a limited attention space.

A limited attention space pertains not just to the political agenda set by elites, but also to the inputs that feed from the public or from citizens into the political apparatus via media. Denser mediated relations mean that political elites, including media elites, have to become more responsive to greater input. Insofar as these inputs have expanded beyond traditional media, this expansion demands a response to a more complex set of media inputs. But it is not just politicians who can target the electorate better, nor just citizens who can select news and other politically-relevant information more and provide more differentiated and more mediated inputs into the political 
apparatus. It is also that news media and politically-relevant information can more accurately target their audiences.

To give just one striking example of this media targeting: Bright and Nichols (2014) have shown, in the case of five major UK news websites, that the 'most read' articles stay on the front page longer than less read articles, which is an indication of a new populism whereby editors cater to the wishes of their audiences. This closer yoking of content with audience demands is in tension with a 'patrician' view of the media, whereby the media should tell the public what's most important. The idea that the media promote the common good is more pronounced in systems with public media (and as we have seen, public media also produce greater political knowledge). Yet this yoking could also be seen as allowing greater responsiveness to citizens, and in this way benefit democracy, as long as citizens are becoming more aware of - and engaged in - political issues. However, there is no evidence of such an overall increase in political engagement due to internet-related changes in media (in addition to the references discussed so far, Hindman 2008 also makes this point). And the effect could also be the opposite: monitoring the public could lead to a skew or misrepresentation of the public because what is being monitored represents a more mediated digital realm rather than the aggregated realm of all (traditional media and offline) inputs. In other words, the increasing reliance on public opinion measurement means reliance on media rather than on votes and the like, and the reliance on digital media adds to this (but again, within the constraints of the media subsystem).

Finally, limited attention and visibility apply not just to content produced and agendas purveyed, but also to content consumed. 'Selection' (or self-self-selection, a term used by Castells 2009) is misleading in the sense that it implies unlimited content. But news consumers or audiences are also limited by the time they devote to political news, which is lower except when there are elections (Boczcowski and Mitchelstein 2013), and the amount of content devoted to public affairs is more 
than they typically want as opposed to what journalists provide (ibid). The discrepancy between what journalists provide and what audiences want to read and watch also comes across in a study which compared agenda-setting in traditional news media with online news media. The study, by Neuman, Guggenheim, Mo Jang and Bae (2014) asked: Do social media (in this case, Twitter, blogs, and discussion forums) differ in terms of agenda setting compared with traditional media? What they found was that 'social media are more responsive to public order and social issues and less responsive to the abstractions of economics and foreign affairs' (2014: 7). What we can see here is the gap opening up between what audiences want and what digital news media provide for them. This, again, is not entirely a zero sum game, but in view of the displacement effect identified by Prior and by Westlund and Weibull, and because peoples' total use of political media use is not simply expanding with each new medium, we can confirm a shift in content as well as in format or channel.

What then, are the dangers or new opportunities of digital media? The main danger is that elites react more to media signals than to non-mediated demands, becoming skewed to the potentially more misrepresentative inputs of digital media. The main opportunity is that the agenda shifts more closely to issues or groups that have been overlooked (though as we have seen, this also includes groups like the Sweden Democrats or 'anti-establishment' outsiders like Donald Trump, who are less represented in traditional media or who would otherwise be more ignored). The combination of the two could be - not polarization, but differentiation, whereby more diverse content and simply more content could enrich the public sphere in some ways and impoverish it in others. The bias of political communication research and research on new technologies is to tell us that a more diverse and content-rich media environment should lead to more political participation and better informed citizens. Yet the result could also be the reverse: more mediation could leave politics the same if the impetus to engagement and the level of interest in politics is the same or declines, or if media become more responsive to extreme political forces. Further, the extent and quality of mediation could leave (some) citizens less engaged and less informed, a constant worry in media research. And 
if the input into the agenda-setting process from the public is more diffuse, this could give more power to political elites, as could a more diffuse media input into the political process by media elites. The position advanced here is thus that political elites are able to manage their communication more and target their messages more powerfully, and the same is true for media elites. Enhancement also applies on the side of awareness and engagement among some citizens as well as some underrepresented groups and their leaders - all of which limited by competition for limited attention or visibility. Hence the benefits of new digital media in coordination and selection are balanced by the diffuseness of engagement and by the constraints of attention.

The crucial change in the political agenda promoted in the media is not that this agenda has become more fragmented or more narrow with digital media. Instead, it has shifted somewhat and become more diversified and differentiated in format and content, even as the overall breadth of this agenda has stayed the same or increased only marginally because of the limited attention space on the one hand, but also the lack of major new social forces to broaden it on the other (Mann 2013; removed for review), though some of the forces identified here on the populist right may yet become major. The shift has thus meant that the added element of public opinion and inputs must be catered for, a coupling which occurs because of a more accurate gauging of public opinion and inputs which can at the same be time skewed towards certain sources. Again, these patterns are part of a longer term trend towards a greater responsiveness to ever more mediated inputs by the public. But we should be wary of equating this greater responsiveness with a more fundamental change in advanced democracies due to digital media.

\section{References}

Aalberg, Toril and Curran, James. 2012. 'Conclusion', in Aalberg, Toril and Curran, James (eds), How Media Inform Democracy: A Comparative Approach. New York: Routledge, pp. 189-200. 
Åsard, Erik and Bennett, W. Lance. 1997. Democracy and the Marketplace of Ideas: Communication and Government in Sweden and the United States. Cambridge: Cambridge University Press.

Barberá, Pablo and Rivero, Gonzalo (2014). Understanding the Political Representativeness of Twitter Users. Social Science Computer Review, (online first) doi:10.1177/0894439314558836

Baum, Matthew and Groeling, Tim. (2008). “New Media and the Polarization of American Political Discourse." Political Communication. 25: 345 - 365.

Bennett, W. L. and lyengar, S. (2008), A New Era of Minimal Effects? The Changing Foundations of Political Communication. Journal of Communication, 58: 707-731.

Bennett, W. L. and Segerberg, A. 2013. The Logic of Connective Action: Digitalization and the Personalization of Contentious Politics. Cambridge: Cambridge University Press.

Bimber, Bruce. 2003. Information and American Democracy. Cambridge: Cambridge University Press.

Bimber, Bruce (2014) Digital Media in the Obama Campaigns of 2008 and 2012: Adaptation to the Personalized Political Communication Environment, Journal of Information Technology \& Politics, $11: 2,130-150$.

Boczkowski, P. \& Mitchelstein, E. (2013). The news gap: When the information preferences of the media and the public diverge. Cambridge, MA: MIT Press.

Bright, Jonathan and Nicholls, Tom. 2014. The Life and Death of Political News: Measuring the Impact of the Audience Agenda Using Online Data, Social Science Computer Review 32: 170-181. 
Castells, Manuel. 2009. Communication Power. Oxford: Oxford University Press.

Chadwick, Andrew. 2013. The Hybrid Media System: Politics and Power. New York: Oxford University Press.

Cook, Timothy. 2005 (2nd ed.). Governing with the News: The News Media as a Political Institution. Chicago: University of Chicago Press.

Curran, J.; lyengar, S.; Brink Lund A. and Salovaara-Moring, I. (2009). “Media System, Public Knowledge and Democracy: A Comparative Study," European Journal of Communication vol. 24(1): $5-26$.

Dahl, Robert. 1998. On Democracy. New Haven: Yale University Press.

Dimitrova, Daniela; Strömbäck, Jesper. 2011. Election news in Sweden and the United States: A comparative study of sources and media frames. Journalism. 13(5) 604-619.

Duggan, M., Ellison, N.B, Lampe, C., Lenhart, A, and Madden, M. (2015) Social Media Update 2014, Pew Research Center, Available at: $\underline{\text { http://www.pewinternet.org/2015/01/09/social-media-update-2014/ }}$ Earl, Jennifer and Kimport, Katrina. 2011. Digitally Enabled Social Change: Activism in the Internet Age. Cambridge MA: MIT Press. 
Findahl, O, \& Davidsson, P. (2015). Svenskarna och Internet, available at https://www.iis.se/docs/Svenskarna och internet 2015.pdf

Golbeck, J., Grimes, J. M. and Rogers, A. (2010), Twitter use by the U.S. Congress. Journal of the Association for Information Science and Technology, 61: 1612-1621.

Gulati, Girish and Christine B. Williams. 2013. Social Media and Campaign 2012: Developments and Trends for Facebook Adoption. Social Science Computer Review. 31: 577-588,

Gustafsson, Nils. 2012. The subtle nature of Facebook politics: Swedish social network site users and political participation, New Media \& Society, vol. 14 no. 7. 1111-1127.

Hallin, Daniel, and Mancini, Paolo. 2004. Comparing Media Systems: Three Models of Media and Politics. Cambridge: Cambridge University Press.

Hedman, Ulrika; Djerf-Pierre Monika (2013), 'The Social Journalist', Digital Journalism, Vol. 1, Issue. 3, 2013.

Hellström, A., Nilsson, T., \& Stoltz, P. (2012). Nationalism vs. nationalism: The challenge of the Sweden Democrats in the Swedish public debate. Government and Opposition, 47(2), 186-205.

Hindman, Matthew. 2008. The Myth of Digital Democracy Princeton: Princeton University Press.

Howard, Philip. 2010. The digital origins of dictatorship and democracy: Information technology and political Islam. Oxford: Oxford University Press. 
McCombs, Maxwell. 2014. Setting the Agenda: Mass Media and Public Opinion. Cambridge: Polity Press.

Larsson, Anders Olof (2013) Tweeting the Viewer-Use of Twitter in a Talk Show Context, Journal of Broadcasting \& Electronic Media, 57:2, 135-152.

Larsson, Anders Olof. 2014. Online, all the time? A quantitative assessment of the permanent campaign on Facebook, New Media \& Society, online first, doi:10.1177/1461444814538798

Larsson, A. O. (2015). Going viral? Comparing parties on social media during the 2014 Swedish election. Convergence: The International Journal of Research into New Media Technologies, doi:10.1177/1354856515577891

Larsson, Anders Olof and Moe, Hallvard. (2012) 'Studying political microblogging: Twitter users in the 2010 Swedish election campaign', New Media \& Society 14: 729-747

Larsson, Anders O; Kalsnes, Bente. 2014. 'Of course we are on Facebook': Use and non-use of social media among Swedish and Norwegian politicians, European Journal of Communication vol. 29 no. 6, 653-667.

Luhmann, Niklas. 2000. The Reality of the Mass Media. Cambridge: Polity Press.

Mann, M. 2013. The Sources of Social Power, vol.4: Globalizations, 1945-2011. Cambridge: Cambridge University Press. 
Messing, Solomon; Westwood, Sean. 2014. Selective Exposure in the Age of Social Media Endorsements Trump Partisan Source Affiliation When Selecting News Online, Communication Research, vol. 41 no. 8 1042-1063

Nielsen, Rasmus Kleis \& Schrøder, Kim Christian (2014) The Relative Importance of Social Media for Accessing, Finding, and Engaging with News, Digital Journalism, 2:4, 472-489.

Norris, Pippa. 2000. A Virtuous Circle: Political Communication in Post-Industrial Societies. Cambridge: Cambridge University Press.

Norris, Pippa and Inglehart, Ronald. 2009. Cosmopolitan Communication: Cultural Diversity in a Globalized World. Cambridge: Cambridge University Press.

Pew Research Center. 2015 (June). Millennials \& Political News, available at http://www.journalism.org/files/2015/06/Millennials-and-News-FINAL-7-27-15.pdf

Prior, Markus. 2007. Post-Broadcast Democracy: How Media Choice Increases Inequality in Political Involvement and Polarizes Elections. Cambridge: Cambridge University Press.

Russell Neuman, W., Guggenheim, L., Mo Jang, S. and Bae, S. Y. (2014), The Dynamics of Public Attention: Agenda-Setting Theory Meets Big Data. Journal of Communication, 64: 193-214.

Schlozman, Kay Lehman; Verba, Sidney and Brady, Henry E. (2010). Weapon of the Strong? Participatory Inequality and the Internet. Perspectives on Politics, 8, pp 487-509. 
Schroeder, Ralph. 2007. Rethinking Science, Technology and Social Change. Stanford: Stanford University Press.

Schroeder, Ralph. 2013. An Age of Limits: Social Theory for the Twenty-First Century. Basingstoke: Palgrave.

Schrøder, Kim Christian (2015) News Media Old and New: Fluctuating audiences, news repertoires and locations of consumption, Journalism Studies, $16: 1,60-78$.

Schudson, Michael. (2011 $2^{\text {nd }}$ ed.) The Sociology of the News. New York: W.W. Norton.

Stockmann, Daniela. (2013). Media Commercialization and Authoritarian Rule in China. Cambridge: Cambridge University Press.

Strömbäck, Jesper; Dimitrova, Daniela. 2011. Mediatization and Media Interventionism: A Comparative Analysis of Sweden and the United States. International Journal of Press/Politics 16(1) $30-49$.

Tomasky, Michael. 2016. Can He Be Stopped? New York Review of Books, April 21 ${ }^{\text {st }}$, http://www.nybooks.com/articles/2016/04/21/can-donald-trump-be-stopped/

Thompson, John B. 1995. The Media and Modernity: A Social Theory of the Media. Cambridge: Polity Press. 
Weibull, Lennart; Wadbring, Ingela. 2014. Mass Medier: Nya villkor för press, radio och tv i det digitala medialandskapet. Stockholm: Ekerlids.

Webster, James. 2005. 'Beneath the Veneer of Fragmentation: Television Audience Polarization in a Multichannel World', Journal of Communication, 55(2): 366-82.

Westlund, O. and Weibull, L. (2013), 'Generation, life course and news media use in Sweden 19862011', Northern Lights 11, pp. 147-173.

Williams, Bruce and Delli Carpini, Michael. 2011. After Broadcast News: Media Regimes, Democracy, and the New Information Environment. Cambridge: Cambridge University Press. 